\title{
ARRIVAL OF THE HOUSE SPARROW ON THE PRAIRIES
}

C. STUART HOUSTON, 863 University Drive, Saskatoon, Saskatchewan S7N 0J 8

It is surprising how little information is available concerning the arrival of the House Sparrow on the Canadian prairies. In part this was because its advent coincided with the flood of settlers, most of whom were quite unaware of the significance of a few sparrows that would have gone unnoticed where these people originated.

South of the border, more attention was paid to this rapidly spreading pest. In fact, the first Bulletin of the U.S. Department of Agriculture was a 405page publication: The English Sparrow in North America, especially in its relation to Agriculture. ${ }^{1}$ In it, Walter $\mathrm{B}$. Barrows documented the spread as far as the twin cities of Minneapolis-St. Paul, Minnesota, by the fall of 1886 , augmented in a minor way by the release of a dozen birds in St. Paul in 1875. ${ }^{14}$ Barrows reported the House Sparrow had spread over more than a half-million square miles of new territory on this continent between 1880 and 1885, and in 1886 alone had spread over another half-million square miles. Although it had occupied 148,000 square miles in eastern Canada by this time, Barrow had negative reports from $A$. McArthur and L. H. Smith of Winnipeg, and from George F. Guernsey of Fort Qu'Appelle, indicating that it had not yet reached the Canadian Northwest.

The House Sparrow did not reach North Dakota for another 7 years. Robert E. Stewart's Breeding birds of North Dakota documents how the first few sparrows reached Fargo on August 6,1893 , when they were nowhere else in the state. There were eight at Cando in the fall of 1894 , with a few raised in 1895; the first definite nest report was of a 'rotten egg and three young' at Stump Lake June 17, 1905. By 1909, they were present in most towns and on most Dakota farms. ${ }^{17}$

The first published record for western Canada was that of John Macoun: "In 1894, a few pairs were seen near the railway station at Winnipeg, Man.; since then they have spread rapidly westward." 11

The most complete record for any prairie locality appears in the diary of Percy Criddle, ${ }^{7}$ further details of which have been provided by his granddaughter, Alma Criddle. On November 10, 1897, Percy recorded that "Sparrows have arrived as far west as Brandon - saw at least 100 feeding and flitting about in the roads yesterday." The first individual reached the Criddle farm, near Aweme post office and north of the hamlet of Treesbank, 25 miles southeast of Brandon on April 8, 1899: "A real common English sparrow around the buildings - whence it came of course no one knows - possibly from Brandon where there are lots." By October 30, 1902, Percy noted "A flight of English sparrows, about 20, around the house - Brandon is now full of them - and little lots often appear here late in autumn, but I've seen none in the summer." On October 30, 1903, Percy noted: "English sparrows getting about - Cullen [a neighbor] has over 100 (about a dozen last year). Now we have several around - Brandon is swarming with them." His final entry on this subject was dated March 9, 1908: "We've 6 or 7 sparrows all through this winter McLeod's [a neighbor] have 20 or $30-$ other farms the same. The little devils are steadily increasing and there'll be trouble presently I expect." The House Sparrow had become a regular and accepted species that did not warrant further mention.

Mitchell in 1924 stated that this species "appears to have invaded Saskatchewan about 1898" but gave no documentation as to localities or observers. ${ }^{12}$ The following comments 


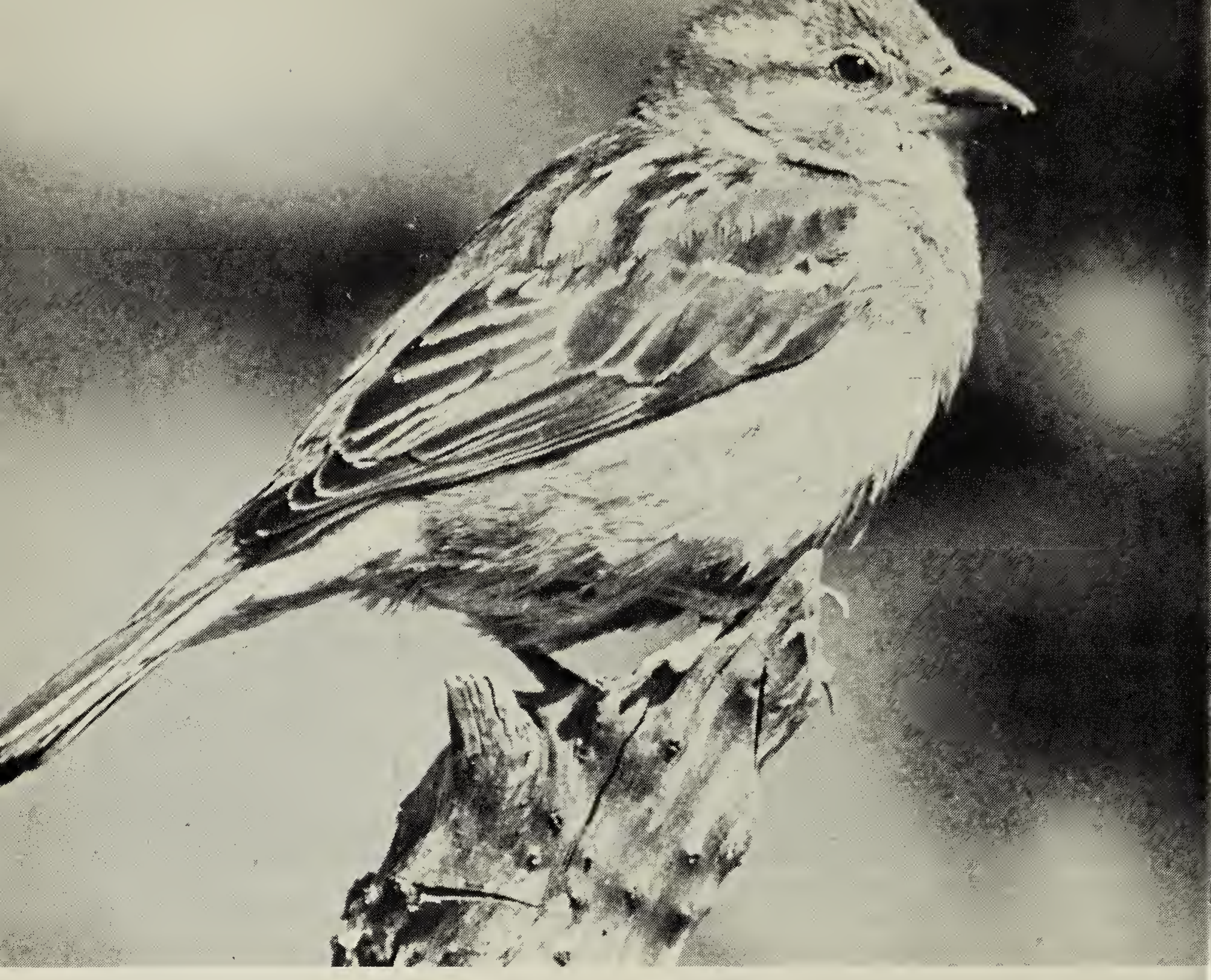

of the oologist, Walter Raine, quoted by Macoun, provide the first nesting records for Saskatchewan: "This bird is gradually extending its range westward and northwestward. I found it nesting at Yorkton, Sask., in June, 1901, and Mr. Hugh Richardson, during the summer of 1901, sent me two sets (of what he called rare eggs) of a bird that had never been seen before in the Qu'Appelle valley, Sask., a bird unknown to him, and they turned out to be only eggs of the English sparrow. I have no record of this bird from Alberta, but it is only a matter of time when it will extend its range right to the Rocky mountain foothills." 11

No House Sparrows were mentioned in the migration records of Miss Esther Wemyss, sent to the United States Biological Survey from Starr Point School, 4 miles south and 3 miles west of Qu'Appelle station, in 1898 and 1899, nor in the records sent under her married name of Esther Cates from Bonnie Brae farm, 9 miles south of
Qu'Appelle, in 1901 or 1902. In the spring of 1903, Mrs. Cates reported that "English sparrows have reached this station." In 1904, English Sparrows were first seen on April 16, next on April 17 and became common on April 20. In 1905, two were seen on March 4, with sightings again on March 5 and they became common on April 9. In 1906, two were seen on March 8, the date they became common. In 1907, the "English House Sparrow" became the first entry on the migration list, on February 10, the day that it "came to the house again ... having wintered round the stables." Thereafter the House Sparrow was a regular yearround resident, omitted from the migration lists of all subsequent years.

Intensive bird surveys in the Maple Creek area in 1905 and 1906, carried out by a group of ornithologists led by A. C. Bent, failed to record the House Sparrow. ${ }^{2}$ The first House Sparrows reached Laurence B. Potter's Gower 


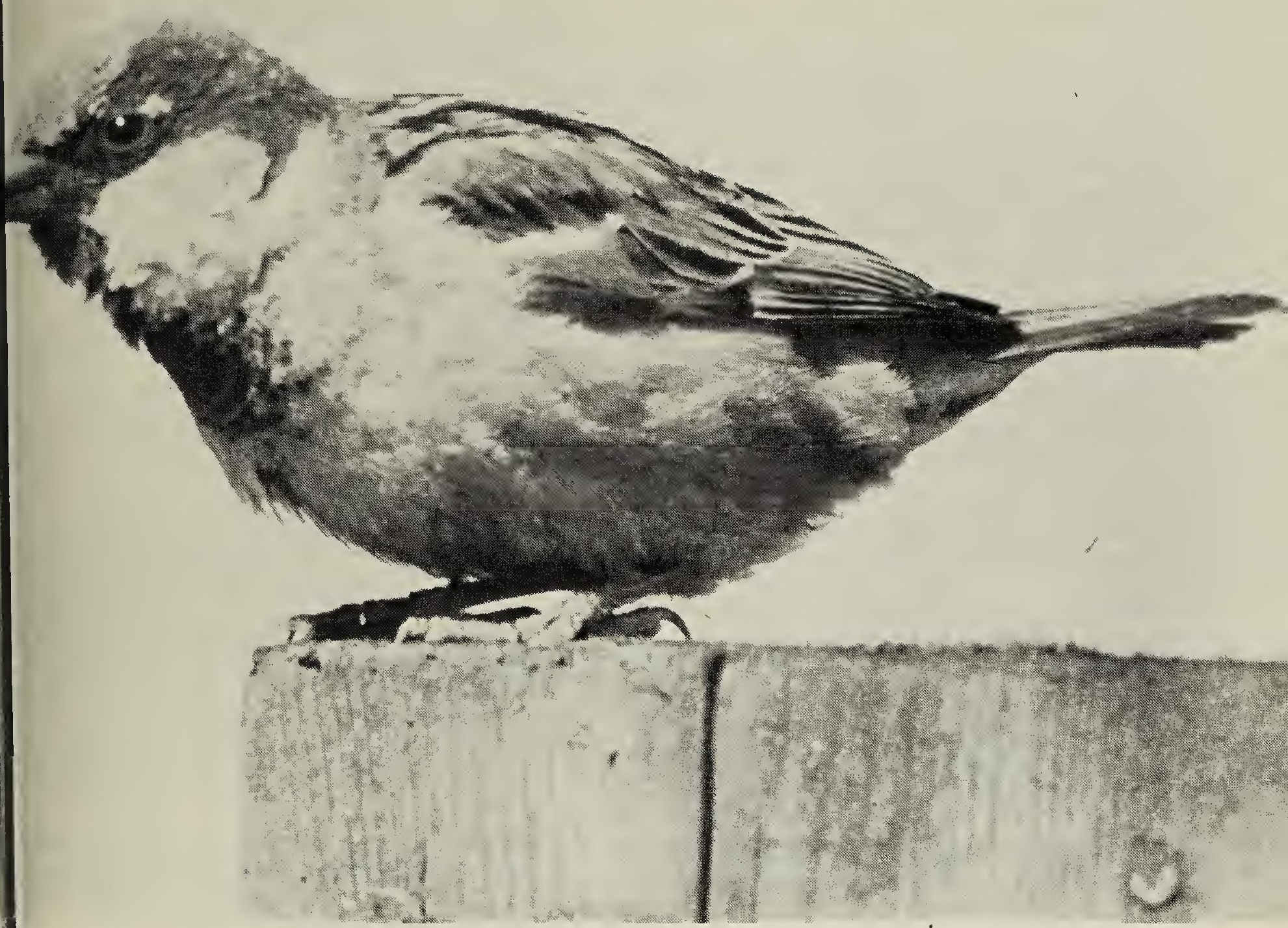

Male House Sparrow

Fred W. Lahrman

Ranch near Eastend on October 6, $907^{13}$

Russell T. Congdon, who studied irds in the Kinistino area in 1902, loted that "This little pest has wanlered to the Saskatchewan region, but loes not yet exist in such large umbers as to be the nuisance that it is arther south." 6 John F. Ferry, in his 909 collecting expedition, noted fouse Sparrows at Prince Albert and t a farm 8 miles southeast of Prince Ibert, and noted one or more at Quill ake on June 27, 1909. ${ }^{9}$ Captain Angus uchanan was somewhat surprised to ind that House Sparrows had already eached Big River on May 12, 1914, nd was even more surprised to find hem at Ile-a-la-Crosse on May 22-24, 914. ${ }^{5}$ A United States Biological urvey party, comprised of Francis larper, Hamilton M. Laing and J. Iden Loring, collected one House parrow at Lake Athabasca in 1920. ${ }^{3}$

The House Sparrow continued to increase in numbers, and there is a note in the annual report of the Saskatchewan Provincial Museum for 1924 that it showed a "continued increase throughout the province. these are coming into the province from the east." ${ }^{\prime 4}$ Maurice Street, after talking to oldtimers, reported that this species probably arrived in the TisdaleNipawin area shortly after the first settlers about 1908. It was seen by Street as early as 1918 and became common by $1925 .^{10}$

It is surprising that J. Dewey Soper had no records for Waskesiu townsite as late as 1952, the only record for Prince Albert National Park being a few seen near the south gate of the park. ${ }^{16}$ By 1960,1 found them common in the Waskesiu townsite.

Although Macoun knew of no Alberta records in 1904, Frank L. Farley had made an unusually early observation of several House Sparrows feeding along the railroad tracks in the 
town of Red Deer in the summer of $1898 .^{8}$

The overall spread of the House Sparrow across North America has been well displayed in a series of maps prepared by Chandler S. Robbins. ${ }^{15}$ The species had reached Edmonton, Alberta, by 1910, but the Rocky Mountains in Canada and an area of northwestern Montana had not yet been invaded at that time. As measured by the Breeding Bird Surveys of 1968, House Sparrows remain sparsely represented wherever human population is sparse, including Nevada, much of Utah, southern Idaho, and all but the northern portion of Montana. ${ }^{15}$ In keeping with this, in the northern half of Saskatchewan we still find House Sparrows restricted to the immediate area of each settlement. It is no wonder that their initial spread coincided closely with that of the human settlers.

Acknowledgements: I wish to thank Chandler S. Robbins, Chief of Migratory Non-Game Bird Studies, U.S. Fish and Wildlife Service, for photocopies of the migration dates submitted to the Biological Survey by the late Mrs. Esther Cates, and Miss Alma Criddle of Winnipeg, for complete relevant excerpts from her grandfather's diary.

'BARROWS, W. B. 1889. The English Sparrow Passer domesticus, in North America, Especially in its Relations to Agriculture. Govt. Printing Office, Washington. 405 pp.
${ }^{2}$ BENT, A. C. 1907 \& 1908. Summer birds of southwestern Saskatchewan. Auk 24:407-430 \& 25:25-35.

${ }^{3}$ BRADSHAW, F. 1921. Report of the Chief Game Guardian for the year ending April 30, 1921. King's Printer, Regina. 53 pp.

${ }^{4}$ BRADSHAW, F. 1925. Report of the Game Commisioner for the year ended April 30 , 1925. King's Printer, Regina. 44 pp.

${ }^{5}$ BUCHANAN, A. 1920. Wild Life in Canada. John Murray, London. 264 pp.

${ }^{6}$ CONGDON, R. T. 1903. Saskatchewan birds. Trans. Wisconsin Acad. 14:569. 620 .

${ }^{7}$ CRIDDLE, A. 1973. Criddle-de-diddle-ensis a Biographical History of the Criddles of Aweme. Alma Criddle, Winnipeg. 288 pp.

${ }^{8}$ FARLEY, F. L. 1932. Birds of the Battle River Region. Institute of Applied Art Edmonton. 85 pp.

${ }^{9}$ FERRY, J. F. 1910. Birds observed i Saskatchewan during the summer o 1909. Auk 27:185-204.

${ }^{10}$ HOUSTON, C. S. and M. G. STREET. 1959 The Birds of the Saskatchewan River Carlton to Cumberland. Sask. Nat. Hist Soc., spec. pub. \#3, Regina. 205 pp.

"MACOUN, J. 1904. Catalogue of Canadia Birds. Part III. S. E. Dawson, Queen' Printer, Ottawa, 345 pp.

${ }^{12}$ MITCHELL, H. H. 1924. Birds of Saskat chewan. Can. Field-Nat. 38:101-118.

${ }^{13}$ POTTER, L. B. 1930. Bird-life changes i twenty-five years in southwester Saskatchewan. Can. Field-Nat. 44:147 149.

${ }^{14}$ ROBERTS, T. S. 1936. Birds of Minnesot: University of Minnesota Press, Mir neapolis. Vol. 2, p. 283.

${ }^{15}$ ROBBINS, C. S. 1973. Introduction, sprea and present abundance of the Hous Sparrow in North America. IN: Symposium on the House Sparrow an European Tree Sparrow in Nort America. Ornith. Monographs \#1 American Ornithologists' Unior Lawrence, Kansas

${ }^{16}$ SOPER, J. D. 1952. The Birds of Prind Albert National Park, Saskatchewai Wildlife Management Bull., Series 2, Nc 4. Canadian Wildlife Service, Ottawa. 9 pp.

${ }^{17}$ STEWART, R. E. 1975. Breeding birds North Dakota. Tri-College Center fo Environmental Studies, Fargo, Nort Dakota. 295 pp. 